\title{
Determining the Impact of Residential Neighbourhood Crime on Housing Investment Using Logistic Regression
}

\author{
Sunday Emmanuel Olajide \\ University Tun Hussein Onn Malaysia \\ Department of Real Estate, Faculty of Technology Management \& Business, Research Assistant, PhD, Malaysia
}

\author{
Mohd Lizam \\ University Tun Hussein Onn Malaysia \\ Department of Real Estate, Faculty of Technology Management \& Business, Senior Lecturer, PhD, Malaysia
}

\begin{abstract}
This paper discusses the impact of criminal activities on residential property value. With regard to criminal activities, the paper emphasizes on the contribution of each component of property crime. One thousand (1000) sets of structured questionnaire were administered on the residents of residential estates within the South Western States of Nigeria out of which 467 were considered useable after the data screening. Purposive and systematic sampling techniques were used while logistic regression was used to determine the impact of each of the components of residential property crime on housing investment. The results showed the P-Values of $0.000,0.322,0.335,0.545$ and 0.992 for violent crime, incivilities and street crime, burglary and theft, vandalism and robbery respectively. However, the $R^{2}$ which represents the generalisation of the impact of neighbourhood crime on housing investment was $44 \%$ and aggregate P-value was 0.000 . Using the Hosmer and Lemeshow $(\mathrm{H}-\mathrm{L})$ test of goodness of fit, the model had approximately $89 \%$ predictive probability which is considered excellent. This indicates that the alternative hypothesis is upheld that residential neighbourhood crime is capable of impacting on residential property value. The policy implication of this result is that no effort should be spared in combating residential neighbourhood crime in order to boost and encourage housing investment.
\end{abstract}

Keywords: Housing investment; Logistic regression; Property values; Residential neighbourhood crime; SocioEnvironmental Design Factors.

UDC 332.6

JEL Classification: L85, R3

DOI: http://dx.doi.org/10.22178/pos.17-13

\section{Introduction}

The importance of housing to humanity cannot be over-emphasized. It ranges from security, social services, investment, recreation and its enormous contributions to the national economy [1]. Housing is however bedevilled by a number of risks which include property crime. The consequences of residential neighbourhood crime affect residents, entire neighbourhood, government activities and in particular housing investment.

The essence of going into housing investment is to make profit which could reflect in whether the value of the property in question is appreciating or not. Literature, no doubt have a very diverse views on the impact of property crime on property values, prominent among the views is the fact that majority see property crime which is otherwise called residential neighbourhood crime as having a significantly negative impact on the property values while a few other researchers see the omnibus affirmation to be inadequate since there exists different types or levels of property crimes [16]. These include burglary and theft; incivility and street crime; vandalism; robbery and violent crime among others. Their position is that there could be variance in the contributions of each of the components of property crime and probably would give a better direction to the government on which crime to place priority on. 
Furthermore, literature revealed that urban crimes are of different types, degrees and nature bur those common to residential neighbourhood have been carefully studied for the purpose of this research. These include burglary and theft, incivility and street crime, vandalism, robbery and violent crimes. Another important point to note is that though all these elements of property crime could impact on housing investment but in different proportions. This is the main thrust of this article.

In view of the foregoing, the intention of this research is to predicatively determine the impact of residential neighbourhood crime as an entity, as well as its sub-variables (burglary and theft; incivility and street crime; vandalism; robbery and violent crime) on residential property values with a view to boosting housing investment. This paper is structured as follows: section two discusses literature review, section three dwells on methodology, section four presents the data analysis while sections five and six center on discussion of findings and conclusion respectively.

\section{Literature Review}

Research works on the consequences of residential property crime have revealed the need to pay better attention to its ultimate control, if not end. The effect is found to be devastating. This cuts across the residential neighbourhood itself. Effect of neighbourhood crime on the neighbourhood take the form of neighbourhood decline, effect on housing sustainability, residential mobility and the negative impact on the housing investment. The burden of property crime also rests on the residents in that it is found to be capable of increasing family budget in the quest of searching for alternative security; property crime is capable of causing psychological fear, poor health and sudden death. Next to this is its negative effect on the general economy and the society at large. This is manifested in the increase in public budget as there may be need to procure more police, judges and also the need to build more prisons. Street incivility had also been found to be capable of negatively affecting governance; government revenue may be reduced especially income from property related tax which by extension may affect the general economy.

Over the years, in order to curb the soaring trend of property crime effort had been intensified by researchers and government departments espe- cially in the developed nations to compliment the traditional crime control strategies (use of police, judicial system and through imprisonment) with the use of environmental design and promotion of social development programmes which have been found to be effective in the area of residential neighbourhood crime control. However, this paper is meant to consider the effect of residential neighbourhood crime and its various elements (burglary and theft, incivility and street crime, vandalism, robbery and violent crimes) on housing investment. For the purpose of this research, the performance of housing investment is measured by the residential property values.

Property crime represents different offenses targeted at the residential neighbourhood as well as its residents. The effect as earlier on mentioned is felt by the neighbourhood, residents and the society in general. Property crime which is otherwise called residential neighbourhood crime ranges from burglary, theft street incivilities, vandalism, and robbery to violent crime. Literature has it that the most frequent offence usually come from burglary due to the fact that valuables are kept in the home and resident are not always in the home. Violent crime which comes in the form of rape, kidnap and murder is found at the other extreme. A cursory look into the literature on how significant the effect of these various types of crime are on changes in residential property values reveals that violent crime is more significant than burglary. This may not be unconnected to its (violent crime) devastating effect on residents' health and the possibility of resulting in sudden death. Burglary in most cases may come in the form of robbery when force and use of dangerous weapons are employed by the offender(s).

The consequences of residential neighbourhood crime on housing investment are said to be grievous, and effort is made in this section of the article to review previous research works with a view to building a solid foundation for this work. Scientists Ihlanfeldt and Mayock [21] opined that the relationship between crime and estate values has a vast research literature connected with it, but several studies are hindered by the fact that it is hard to separate the precise variables and trait declines in value directly to an offense. Their study "Panel Data Estimates of the Effects of Different Types of Crime on Housing Prices," found that among seven kinds of crime studied, "only aggravated assault and robbery crimes (per acre) 
exercise a significant influence upon neighbourhood residential property values".

The extent of the possible impacts of crime on property values is examined in a 2012 paper by the Center for American Progress. It studied the direct and indirect financial burden of homicide in Seattle, Milwaukee, Houston, Dallas, Boston, Philadelphia, Chicago and Jacksonville (eight U. S. metropolitan areas). The annual direct financial burden of the violent offense in the eight cities equalled $\$ 3.7$ billion per year, an aggregate of $\$ 320$ a person annually. The influence on housing values was also large, and the study shows that a $10 \%$ decrease in murders would translate to a $0.83 \%$ appreciation in housing values the subsequent year.

These relationships may vary in various socioeconomic districts, and be county- or nationspecific. A 2012 statement by the Federal Reserve Bank of New York, "Crime, House Prices, and Inequality," examined at how the things work out in Latin America [26]. The authors discovered that a drop of crime created by intensified policing in Rio de Janeiro presented a fall in crime and an increase in housing values: Robberies $10 \%$ and $20 \%$ and murders decreased from $10 \%$ to $25 \%$, while the disposal price of the houses increased between $5 \%$ and $10 \%$ - and was correspondingly greater in low-income communities. Besides, the study found meaningful evidence to state that from 2008 to mid-2011, improved policing produced a $15 \%$ rise in formal property transactions.

Furthermore, there are different types of crime, and associated thoughts, that have also been investigated. A 2008 study in American Economic Review, "Estimates of the Impact of Crime Risk on Property Values from Megan's Laws," observed that property prices within 0.1 miles of a designated sex criminal fall by $4 \%$ on a normal situation. The scholars, Linden and Rockoff [24] demonstrated the impact in this manner: "Residents by way of responding to crime risk usually have two choices: they can choose anti-crime policies, or they can decide with their feet. When individuals apply the latter alternative, local response to the offense would be perceived in the property market".

There was a declaration that crime offered an intimidation to the housing security of communities, and that researchers often endeavour to measure this indirect cost of crime regarding the influence on property values [3]. They discovered that some researches had unearthed that violent crime results in lower housing prices, but the relationships found between property crime and housing values have been rather vague. Their research hypothesized that price-based models likely undervalue the actual burden of crime since such models depend on transactions to determine prices. However, according to them, if offense hinders sales, price criteria relying on sales may provide incorrect models of changes in housing demand in markets characterized by very low rates of home sales. Similarly, they submitted that price may be a poor indicator of crime-induced shifts in demand in markets characterized by elastic supply. To address this, they estimate the influence of violent, property, and overall offense and variations in crime on the rate of home transactions across Los Angeles communities between 1993 and 1997 and their outcomes show both greater vacancy rates and tremendous levels of offense in the previous year related to higher rates of housing transactions. However, their findings further revealed that the effect of crime-inhibiting sales seems principal due to a further violent offense in districts with high degrees of vacancies and crime.

Crime, according to G. Tita [38] serves as an important catalyst for the transformation of the endemic in reported crime statistics. Their results showed that a remarkable effect of crime rates on house prices could be misleading. The study found that criminality is measured at diverse rates for wealthy, middle class and poor neighbourhoods and that violent crime invokes the greatest burden. socio-economic status of any given communities. While such development occurs over a long period, offending is being described to be benefited to local housing markets quickly and thereby providing an early pointer of neighbourhood transition. Using hedonic regression, they quantified this "intangible cost" of crime and extended the crime-housing price literature in several important ways. First, they disaggregate crime to the census tract level. Second, using longitudinal data, they examined changes in crime in addition to the neighbourhood levels of crime. Third, they differentiated between the effects of property crime and violent crime. Fourth, they also disaggregate their sample into groups based on per capita goods per 
income of the census tract. Finally, they show that it is vital to account for the measurement error.

The research findings of Buonanno [4] on "housing $484 \%$ of the national offense average, however, they begin to have an adverse influence. Park size was irrelevant to offense level, with all dimensions of parks in the low, medium, and high offense categories. Parks found near water also diverged widely according to crime levels, "suggesting that wage unrevealed that when the trend in crime rates of parks or similar conveniences are comparatively low, the prices and crime perception" suggested that crime uses related costs ahead of its immediate costs. Indeed, an increase of one standard deviation in observed security is connected with a $0.57 \%$ rise in the valuation of neighbourhoods. Moreover, in neighborheived as being less secure than the proportion for the City of Barcelona, houses are highly discounted. Less secure neighbourhoods have in a normal situation, a valuation that is $1.27 \%$ lower". The principal judgments of Troy [41] is that they have a decisive influence on property values. When the trend in the crime rates traverse a threshold of between 406\%, amenities do not always yield concrete influences on the property". The neighbourhood of low- and high-crime parks opposite Baltimore was found to be widely scattered throughout the city. "Often, low-crime parks would be detected very close high-crime parks without intermediate medium-crime parks in between".

From the previous, enough evidence exists on the diverse views on the impact of residential neighbourhood crime on property values which calls for concerted effort in unravelling the mystery through meaningful research on this subject until the housing investment is devoid of the threat of property crime. Hence, the need for this research works.

\section{Conceptual Framework}

For the purpose of this research, the SocioEnvironmental Design Factors (SEDeF) model is prescribed. This concept was formulated by Olajide and Lizam [30]. The model is derived from two neighbourhood crime prevention theories. These are Crime Prevention through Social Development (CPSD) and Crime Prevention through Environmental Design (CPTED). CPSD dwells on the philosophy that if the social development factors (poverty, illiteracy, unemployment, poor parenting and homelessness among others) which are regarded as the root causes of crime are tenaciously tackled, that it is capable of stemming down criminal tendencies. Researches had supported it that poverty, illiteracy, unemployment, homelessness and poor parenting are capable of influencing criminal tendencies [19, $42,30]$. CPTED on the other hand opines that the tactical and purposeful manipulation of the residential neighbourhood design is capable of discouraging potential offenders to commit crime $[12,9,10]$. The key elements of CPTED include access control, surveillance, maintenance, target hardening and territoriality among others. These elements of CPTED visualize on a virtual house and neighborhood, that is, designing the residential environment with cognizance to effective maintenance, provision of natural (designed window and doors to control intruders), formal surveillance (police patrol) and mechanical surveillance (use of lighting and CCTV); creating sense of ownership and creating means of controlling the intruders. The tenets of crime opportunity theories form the main thrust upon which the two aforementioned theories are based.

The relevance of this concept is built upon the premise that with many research works as well as practical application of these theories in developed nations like US, UK, Canada, Australia and others few ones in Europe and Asia attesting to their potency in crime prevention, it is our belief that once residential neighbourhood is tackled, it will definitely reflect in boosting housing investment through appreciated property values.

\section{Methodology}

Logistic regression analysis was used to predict the degree of the impact of the various forms of Residential Neighbourhood Crime (RNC) on Residential Property Values (RPV). The components of RNC as revealed in the literature included burglary and theft, incivility and street crime, vandalism, robbery and violent crime [28, $35,17]$.

A total of 1000 sets of questionnaire were randomly distributed to the residents (heads of household) of selected residential neighbourhoods within the Southern-Western Nigeria. Out of the 1000 sets of questionnaire administered, 
728 were retrieved and after the data screening (missing data, outliers and multicollinearity), only 467 sets of questionnaire were found to be clean data and as such were subsequently used for the analysis of this research. Purposive and stratified multi-stage sampling techniques were adopted in the selection of the residential estates as well as the residential buildings from which the heads of the household were used to respond to the questionnaire. As regards the variable used for the analysis, the independent variables represented the various forms of RNC as earlier highlighted while the dependent variable represented the Residential Property Values (RPV). Content validity was adopted to ascertain the appropriateness of the research instrument. As regards the research instrument (questionnaire), the dichotomous approach was explored which was based on two sets of measurement variables: Whether or not residents were aware of Residential Neighbourhood Crime in their estate and (2) whether or not each of the components of RNC has impact on RPV.

J. Pallant [33] highlighted the benefits and desirability of logistic regression. According to her, logistic regression allows for assessment of how well one's set of predictor-variables predicts or explains one's categorical dependent variable. It gives an indication of the adequacy of the model (set of predictor variables) by assessing "goodness of fit". It also provides an indication of the relative importance of each predictor variable or the interaction among the predictor variables. It provides a summary of the accuracy of the classification of cases based on the mode, allowing the calculation of the sensitivity and specificity of the model and the positive and negative predictive values. J. Pallant added that though logistic regression does not take assumption concerning the distribution of scores for the predictor variables; however, it is said to be sensitive to high correlations among the predictor variables (multicollinearity). Outliers as well could influence the results of logistic regression.

An additional descriptive measure of goodnessof-fit presented is the $\mathrm{R}^{2}$ indices as defined by Cox and Snell [8] and Nagelkerke [29], respectively. In linear regression, $\mathrm{R}^{2}$ has a clear definition: It is the proportion of the variation in the dependent variable that can be explained by predictors in the model. Attempts have been devised to yield an equivalent of this concept for the lo- gistic model. None, however, renders the meaning of variance explained [23, 27]. Furthermore, none corresponds to predictive efficiency or can be tested in an inferential framework [27]. For these reasons, a researcher can treat the $\mathrm{R}^{2}$ indices as supplementary to other, more useful evaluative indices, such as the overall evaluation of the model, tests of individual regression coefficients, and the goodness-of-fit test statistic.

All these were painstakingly noted and avoided in order to present a reliable result.

\section{Data Analysis}

The hypothesis of this research relates to testing the impact of Residential Neighbourhood Crime (RNC) on Residential Property Values (RPV). Simply put, "There is a significant and direct impact of residential neighbourhood crime on property values". The hypothesis was tested by (1) considering the impact of residential neighbourhood as an entity on property (housing) values and (2) by measuring the contribution of the various elements of residential neighbourhood crime to the effect. These subvariables under RNC are Burglary and Theft (RNCRPV1); Incivility and Street Crime (RNCRPV2); Vandalism (RNCRPV3); Robbery (RNCRPV4) and Violent Crime (RNCRPV5). By implication, the independent variable is the residential neighbourhood crime (RNC) having its elements (burglary and theft, incivility and street crime, vandalism, robbery and violent crime) as sub constructs while the residential property values stood as the dependent variable (RPV). Residential property value is adopted as the dependent variable on the premises it remains the best parameter to measure the prosperity level of housing investment in general.

The report of the analysis is demonstrated in the next section of this report (Table 1, Table 2).

All the predictors have influences on Residential Property Values (RPV), but the one with a statistical significance is violence crime with an odd ratio of 71.1252 and with parameter value of 4.2644 at $5 \%$ level of significance.

Predictive ability of the model shows by Figure 1. 
Table 1 - Logistic regression Table Using Odd Ratio

\begin{tabular}{|c|c|c|c|c|c|c|}
\hline RNC Aware & Odd Ratio & Std. Error & $(\mathrm{z})$ & $\mathrm{P}>(\mathrm{z})$ & 95\% Conf. & Interval \\
\hline RNCRPV1 & .6286312 & .3029263 & -0.96 & 0.335 & .2444651 & 1.616497 \\
\hline RNCRPV2 & 1.561428 & .7025892 & 0.99 & 0.322 & .6464133 & 3.771669 \\
\hline RNCRPV3 & 1.337629 & .6422731 & 0.61 & 0.545 & .5219448 & 3.428047 \\
\hline RNCRPV4 & .994079 & .6210787 & -0.01 & 0.992 & .292152 & 3.382462 \\
\hline RNCRPV5 & 71.12524 & 29.93818 & 10.13 & 0.000 & 31.16982 & 162.298 \\
\hline _cons & .3345003 & .3210206 & -1.14 & 0.254 & .0509914 & 2.194301 \\
\hline Model & \multicolumn{6}{|c|}{-0.4642RNCRPV1+0.4456RNCRPV2+0.2909RNCRPV3-0.0059RNCRPV4+4.2644RNCRPV5 } \\
\hline \multicolumn{2}{|c|}{ Number of observation } & \multicolumn{5}{|c|}{467} \\
\hline \multicolumn{2}{|c|}{ Chi Square } & \multicolumn{5}{|c|}{144.89} \\
\hline \multicolumn{2}{|l|}{ P-Value } & \multicolumn{5}{|c|}{0.0000} \\
\hline \multicolumn{2}{|l|}{$\mathrm{R}^{2}$} & \multicolumn{5}{|c|}{0.4385} \\
\hline
\end{tabular}

Table 2 - Logistic Regression Using Coefficient

\begin{tabular}{|l|r|r|r|r|r|r|}
\hline RNC Aware & \multicolumn{1}{|c|}{ Coef. } & \multicolumn{1}{c|}{ Std. Error } & \multicolumn{1}{c|}{$(\mathrm{z})$} & \multicolumn{1}{c|}{$\mathrm{P}>(\mathrm{z})$} & \multicolumn{1}{c|}{ 95\% Conf. } & \multicolumn{1}{c|}{ Interval } \\
\hline RNCRPV1 & -0.4642106 & 0.4818824 & -0.96 & 0.335 & -1.408683 & 0.4802615 \\
\hline RNCRPV2 & 0.4456007 & 0.4499658 & 0.99 & 0.322 & -0.4363161 & 1.327518 \\
\hline RNCRPV3 & 0.2908987 & 0.4801579 & 0.61 & 0.545 & -0.6501934 & 1.231991 \\
\hline RNCRPV4 & -0.0059386 & 0.624778 & -0.01 & 0.992 & -1.230481 & 1.218604 \\
\hline RNCRPV5 & 4.264442 & 0.420922 & 10.13 & 0.000 & 3.439450 & 5.089434 \\
\hline _cons & -1.095118 & 0.959702 & -1.14 & 0.254 & -2.976099 & 0.7858637 \\
\hline
\end{tabular}

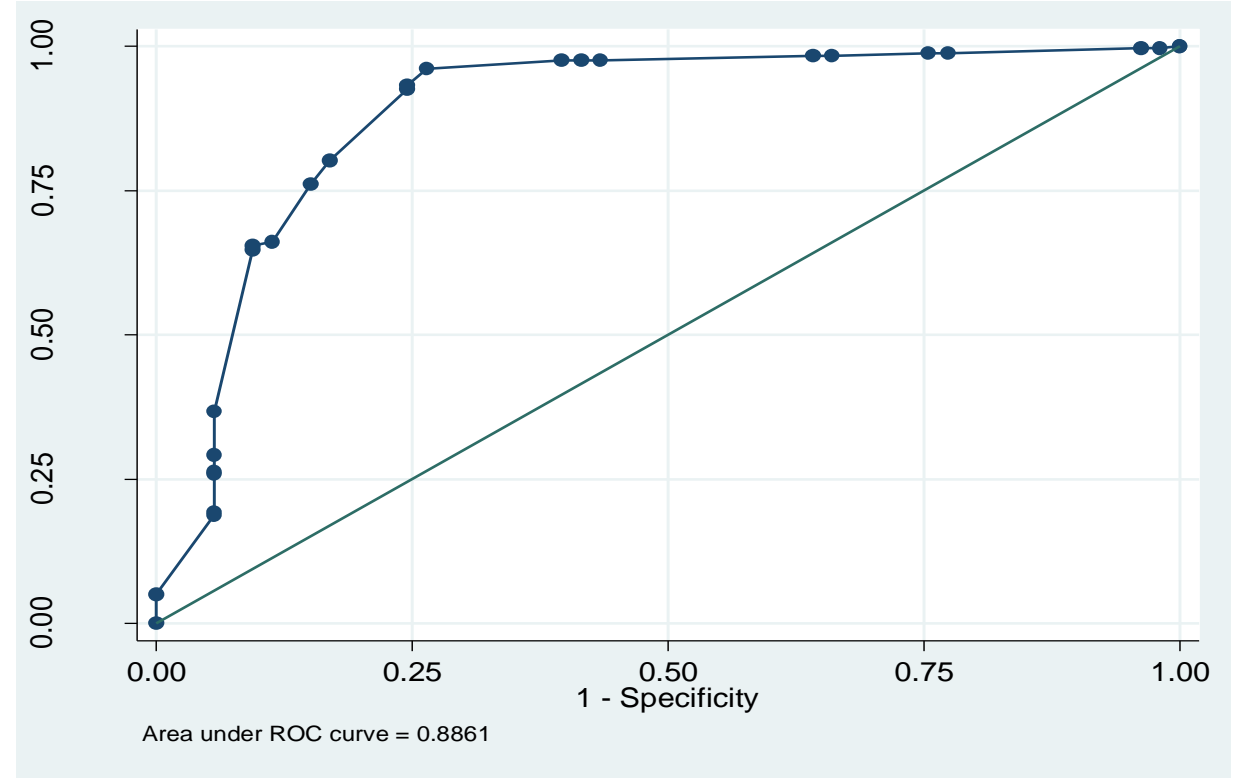

Figure 1 - Logistic model for RNCRPV Aware

Note: Number of observations $=467$; area under ROC curve $=0.8861$. Interpretation: the model has approximately $89 \%$ predictive ability which is excellent.

\section{Results and Discussions}

Precisely, the analysis was carried out based on the objective of the research which set out the hypothesis of predicatively determining the im- pact of the residential neighbourhood crime (RNC) on the residential property values (RPV). In line with the ethics of logistic regression, the questions were set out to suite the outcome of 
the analysis. The sub-variables of the RNC (burglary and theft; incivility and street crime; vandalism; robbery and violent crime) were set out against the RPV which gave rise to the development of the logit regression model. The model was found to be fit after meeting some of the parameters of fitness earlier on mentioned in the previous sections.

From the analysis, the following inferences could be made to support the fitness of the alternative hypothesis that residential neighbourhood crime has significant influence on the residential property values.

1. The P-Value for the entire model showed 0.000 which is less than the requirement of $\leq 0.05$ [33].

2. The $\mathrm{R}^{2}$ of the model which stood at 0.4385 or $44 \%$ which is considered adequate [27].

3. The predictive ability of the model shown through the ROC curve standing at $89 \%$ which could be defined to be excellent [20].

Furthermore, all the predictors have influences on Residential Property Values (RPV), but the one with a statistical significance is violent crime with an odd ratio of 71.1252 and with parameter value of 4.2644 at $5 \%$ level of significance. This, in agreement with Greenbaum \& Tita [18] and Lynch \& Rasmussen [25] was due to the fact that violent crimes attract more fear of crime than burglary and other street incivilities. They affirmed that though residents believed burglary is more frequent in residential neighbourhood crime more than violent crimes. The effect of violent crime on residential mobility and neighbourhood decline was higher. From the foregoing, the relationship between the hypothesis and findings is that the result indicated that the alternative hypothesis should be upheld. That is, there existed significant impact of residential neighbourhood crime on residential property value. By implication, from the respondents' point of view the gravity of crime within a given residential neighbourhood is capable of determining behaviour of the values of such property which in effect defines the buoyancy housing investment.

\section{Conclusion}

This research was embarked upon with the purpose of making predictions as to the impact of different components of residential neighbourhood crime (burglary and theft; incivility and street crime; vandalism; robbery and violent crime) on residential property values. From the last two sections of this article (data analysis and discussion on research findings), it was revealed that there is support for the alternative hypothesis that residential neighbourhood crime has a remarkable impact on the residential property values. This is shown from the P-Value of the entire model $(0.000)$. However, out of the five subvariables of residential neighbourhood crime under consideration, the one with a statistical significance is violence crime with the $p$-value of 0.000. This however does not translate to the fact that other RNC variables have no impact on RPV but only that they are not as significant as violent crime. In terms of hierarchical arrangement of the sub-variables, it can be said to be in this order: incivility and street crime (0.322), burglary and theft $(0.335)$, vandalism $(0.545)$ and robbery (0.992).

The policy implication of this research is that the research is in agreement with previous research works $[21,3]$ that the negative influence of the residential neighbourhood crime on residential property values is capable of spelling doom for housing investment which could manifest in the areas of residential neighbourhood decline, abnormal residential mobility, low productivity in housing investment and a reduction in government revenue through property tax which is capable of negatively affecting the general economy (Gross Domestic Product).

To this end, it is therefore worthwhile to assert that RNC needed to be tackled headlong. Nigeria like other developing economies depends majorly on the penal system (use of police, courts, and prison) to control crime which research have proven to be grossly in adequate $[31,36]$, hence the need to apply a more reliable measure as a supplement if not substitute in order to checkmate neighbourhood crime thereby boosting housing investment. Olajide and Lizam [30] recommended the use of social development programmes that centers on combating the fundamental crime risk factors like poverty, illiteracy, homelessness, unemployment, family disintegration and juvenile delinquencies to mention a few. Also recommended is the application of the principles of crime prevention through environmental design (CPTED). The principle cuts across purposeful manipulation of the residential neighbourhood through design. This is expected to address concepts of territorial functioning, 
natural access, surveillance, target hardening and general maintenance with the main purpose of discouraging intending offender.

Previous research works $[32,10,14]$ centered on Africa and other developing countries founded outside the western countries found out that these principles are yet to be fully exploited which is evident in the soaring rate of property crime within their domain. Many Western countries and continents like US, UK, Canada, Australia and few others in Europe and Asia were found to be enjoying the benefits of these concepts through establishment of the Department of Crime Prevention which gives room for up-todate research on modern crime prevention techniques. Nigeria and other developing countries have a lot to learn and imbibe from these crime prevention principles if RNC is to be drastically reduced in order to further encourage housing investment considering the relevance of housing to mankind.

\section{References}

1. Agunbiade, M. E. (2012). Land Administration for Housing Production (Doctoral thesis, University of Melbourne). Retrieved from http://csdila.unimelb.edu.au/publication/journals/ts05b_agunbiade_rajabifard_et_al_4809.pdf

2. Austin, J. T., Yaffee, R. A., \& Hinkle, D. E. (1992). Logistic regression for research in higher education. Higher Education: Handbook of Theory and Research, 8, 379-410.

3. Boggess, L. N., Greenbaumb, R. T., \& Tita, G. E. (2013). Does crime drive housing sales? Evidence from Los Angeles. Journal of Crime and Justice, 36(3), 299-318. doi: 10.1080/0735648X.2013.812976

4. Buonanno, P., Montolio, D., \& Raya-Vílchez, J. M. (2013). Housing Prices and Crime Perception, Empirical Economics, 45(1), 305-321. doi: 10.1007/s00181-012-0624-y

5. Cabrera, A. F. (1994). Logistic regression analysis in higher education: An applied perspective. Higher Education: Handbook of Theory and Research, 10, 225-256.

6. Shapiro R., \& Hassett, K. (2012). The Economic Benefits of Reducing Violent Crime. Retrieved from https://cdn.americanprogress.org/wp-content/uploads/issues/2012/06/pdf/violent_crime.pdf

7. Chuang, H. L. (1997). High school youth's dropout and re-enrollment behavior. Economics of Education Review, 16(2), 171-186. doi: 10.1016/S0272-7757(96)00058-1

8. Cox, D. R., \& Snell, E. J. (1989). The analysis of binary data (2nd ed.). London: Chapman and Hall.

9. Cozens, P. (2014). Think crime! Using evidence, theory and crime prevention through environmental design (CPTED) for planning safer cities. Quinns Rocks: Paxis Education.

10. Cozens, P., \& Love, T. (2015). A review and current status of crime prevention through environmental design (CPTED). Journal of Planning Literature, 30(4), 393-412. doi: $10.1177 / 0885412215595440$

11. Cozens, P., \& Melenhorst, P. (2015). Exploring community perceptions of crime and crime prevention through environmental design (CPTED) in Botswana. In Papers from the British Criminology Conference (Vol. 14, pp. 65-83). Retrieved from http://britsoccrim.org/new/volume14/pbcc_2014_cozens.pdf

12. Crowe, T. D., National Crime Prevention Institute (University of Louisville). (1991). Crime prevention through environmental design: Applications of architectural design and space management concepts. Boston: Butterworth-Heinemann.

13. Eck, J. E. (1993). The threat of crime displacement. Criminal Justice Abstracts, 25(3), 527-546. Retrieved from http://www.popcenter.org/library/psq/1993/Summer_1993_Vol_6_No_3.pdf

14. Ekblom, P., Armitage, R., Monchuk, L., \& Castell, B. (2013). Crime prevention through environmental design in the United Arab Emirates: a suitable case for reorientation? Built Environment, 39(1), 92-113. doi: 10.2148/benv.39.1.92

15. Frischtak, C., \& Mandel, B. R. (2012, January 1). Crime, House Prices, and Inequality: The Effect of UPPs in Rio. doi: 10.2139/ssrn.1995795

16. Gibbons, S. (2004). The Costs of Urban Property Crime*. The Economic Journal, 114(499), F441F463. doi: 10.1111/j.1468-0297.2004.00254.x

17. Grabosky, P. (1995). Burglary prevention. Trends \& Issues in Crime and Criminal Justice, 49. Retrieved from http://aic.gov.au/media_library/publications/tandi_pdf/tandi049.pdf 
18. Greenbaum, R. T., \& Tita, G. E. (2004). The impact of violence surges on neighbourhood business activity. Urban Studies, 41(13), 2495-2514. doi: 10.1080/0042098042000294538

19. Hastings, R. (2008). Prévenir le crime : réduire la criminalité et accroître la sécurité dans un Canada ouvert à tous [Achieving Crime Prevention: Reducing Crime and increasing Security in an inclusive Canada]. Ottawa: University of Ottawa (in French).

20. Hosmer, D. W., \& Lemeshow, S. (2000). Introduction to the logistic regression model. In Applied Logistic Regression (2nd ed.) (pp. 1-30). doi: 10.1002/9781118548387.ch1

21. Ihlanfeldt, K., \& Mayock, T. (2010). Crime and housing prices. In B. Benson, P. Zimmerman, Handbook on the economics of crime (pp. 303-327). Cheltenham Glos: Edward Elgar Publishing.

22. Lei, P.-W., \& Koehly, L. M. (2003). Linear discriminant analysis versus logistic regression: A comparison of classification errors in the Two-Group Case. The Journal of Experimental Education, 72(1), 25-49. doi: 10.1080/00220970309600878

23. Long, J. S. (1997). Regression models for categorical and limited dependent variables. London: Sage.

24. Linden, L., \& Rockoff, J. E. (2008). Estimates of the impact of crime risk on property values from Megan's laws. The American Economic Review, 98(3), 1103-1127. doi: 10.1257/aer.98.3.1103

25. Lynch, A. K., \& Rasmussen, D. W. (2001). Measuring the impact of crime on house prices. Applied Economics, 33(15), 1981-1989. doi: 10.1080/00036840110021735

26. Maximino, M. (2014, March 12). The impact of crime on property values: Research roundup. Retrieved from https://journalistsresource.org/studies/economics/real-estate/the-impact-ofcrime-on-property-values-research-roundup

27. Menard, S. (2000). Coefficients of determination for multiple logistic regression analysis. The American Statistician, 54(1), 17-24. doi: 10.2307/2685605

28. Moreto, W. (2010). Risk factors of urban residential burglary. RTM Insights, 4, 1-3. Retrieved from http://www.rutgerscps.org/uploads/2/7/3/7/27370595/burglaryrisks.pdf

29. Nagelkerke, N. J. D. (1991). A note on a general definition of the coefficient of determination. Biometrika, 78(3), 691-692. doi: 10.2307/2337038

30. Olajide, S, E. \& Lizam, M. (2016). Residential neighbourhood Security challenges: Assessing crime prevention concepts and Techniques. International Journal of Academic Research and Development, 1(9), 7-15.

31. Olajide, S. E., Lizam, M., \& Adewole, A. (2015). Towards a crime-Free Housing: CPTED versus CPSD. Journal of Environment and Earth Science, 5(18), 53-63. Retrieved from http://www.iiste.org/Journals/index.php/JEES/article/view/26022/26570

32. Owusu, G., Wrigley-Asante, C., Oteng-Ababio, M., \& Owusu, A. Y. (2015). Crime prevention through environmental design (CPTED) and built-environmental manifestations in Accra and Kumasi, Ghana. Crime Prevention \& Community Safety, 17(4), 249-269. doi: 10.1057/cpcs.2015.8

33. Pallant, J. (2011). SPSS Survival Manual. A step by step guide to data analysis using the SPSS program (4th ed.). Sydney: Allen \& Unwin.

34. Peng, C. J. \& Lee, K. L. \& Ingersoll, G. M. (2002). An Introduction to Logistic Regression Analysis and Reporting. The Journal of Educational Research, 96(1), 3-14. doi: 10.1080/00220670209598786.

35. Ratcliffe, J. (2001). Policing urban burglary. Trends \& Issues in Crime and Criminal Justice, 213. Retrieved from http://www.aic.gov.au/media_library/publications/tandi_pdf/tandi213.pdf

36. Sutton, A., Cherney, A., \& White, R. (2013). Crime prevention: principles, perspectives and practices. Cambridge: Cambridge University Press.

37. Tabachnick, B. G., \& Fidell, L. S. (2001). Using multivariate statistics (4th ed.). Needham Heights, MA: Allyn \& Bacon.

38. Tita, G. E., Petras, T. L., \& Greenbaum, R. T. (2006). Crime and Residential Choice: A Neighborhood Level Analysis of the Impact of Crime on Housing Prices. Journal of Quantitative Criminology, 22(4), 299-317. doi: 10.1007/s10940-006-9013-z

39. Tolman, R. M., \& Weisz, A. (1995). Coordinated community intervention for domestic violence: The effects of arrest and prosecution on recidivism of woman abuse perpetrators. Crime and Delinquency, 41(4), 481-495. doi: 10.1177/0011128795041004007

40. The John Howard Society of Alberta. (1995). Crime Prevention through Social Development: $A$ Literature Review. Retrieved from http://www.johnhoward.ab.ca/pub/old/pdf/C6.pdf

41. Troy, A., \& Grove, J. M. (2008). Property values, parks, and crime: A hedonic analysis in Baltimore, MD. Landscape and urban planning, 87(3), 233-245. doi: 10.1016/j.landurbplan.2008.06.005 
42. Waller, I., \& Weiler, D. (1985). Crime prevention through social development. Ottawa: Canadian Council on Social Development. Retrieved from https://www.ncjrs.gov/pdffiles1/Digitization/103113NCJRS.pdf

(C) S. E. Olajide, M. Lizam

\title{
Определение влияния уровня преступности жилого микрорайона на инвестиции в жилищное строительство с использованием логистической регрессии
}

\author{
Sunday Emmanuel Olajide \\ University Tun Hussein Onn Malaysia \\ кафедра недвижимости, факультет технологического менеджмента и бизнеса, \\ научный сотрудник, $\mathrm{PhD}$, Малайзия \\ Mohd Lizam \\ University Tun Hussein Onn Malaysia \\ кафедра недвижимости, факультет технологического менеджмента и бизнеса, \\ старший преподаватель, PhD, Малайзия
}

\begin{abstract}
Аннотация. В данной статье рассматривается влияние преступной деятельности на стоимость жилой недвижимости. Что касается преступной деятельности, в работе подчеркивается вклад каждого компонента имущественных преступлений. Одна тысяча (1000) комплектов структурированного вопросника были предложены жителям жилых комплексов в южно-западных штатах Нигерии, из которых 467 были признаны полезными после скрининга данных. Использовались целенаправленные и систематические методы выборки, в то время как логистическая регрессия была использована для определения влияния каждого из компонентов преступной деятельности, связанной с жилой недвижимостью на инвестиции в жилье. Результаты показали, P-Values 0,000, 0,322, 0,335, 0,545 и 0,992 для насильственных преступлений, неучтивости и уличной преступности, взломов и краж, вандализма и грабежа соответственно. Тем не менее, $\mathrm{R}^{2}$, который представляет собой обобщение влияния преступности на инвестиции в жилищное строительство, составил $44 \%$, а совокупное Р-значение составило 0,000. С помощью теста Хосмера и Лемешова (H-L), теста на эффективность и достоверность, модель имела примерно 89\% прогностической вероятности, что считается отличным результатом. Это указывает на то, что поддерживается альтернативная гипотеза, о том, что преступность жилого района способна воздействовать на стоимость жилой недвижимости. Политическое значение этого результата состоит в том, что никаких усилий не следует жалеть в борьбе с преступностью жилого микрорайона с целью увеличения и поощрения инвестиций в жилищное строительство.
\end{abstract}

Ключевые слова: инвестиции в жилищное строительство; логистическая регрессия; стоимость недвижимости; преступность в жилом микрорайоне; социально-экологические факторы.

УДК 332.6

JEL Classification: L85, R3

DOl: http://dx.doi.org/10.22178/pos.17-13

(C) S. E. Olajide, M. Lizam

Статья получена 02.12.2016, принята 22.12.2016, опубликована оnline 25.12.2016 